\title{
Inventory of scientific publications on urban forestry published between 1800 and 2015: An analysis by period, topic and origin
}

\author{
by Jacques Larouche ${ }^{1 *}$, Danny Rioux², Adrina C. Bardekjian ${ }^{3}$ and Nancy Gélinas ${ }^{1}$
}

\begin{abstract}
Research in urban forestry (UF) is rapidly evolving. In order to better understand this increased interest among the scientific community, a comprehensive inventory of scientific articles published between 1800 and 2015 on the subject was carried out. To do so, 21 keywords were used to query six different databases. Data was gathered and analyzed using the Endnote $x 7$ reference management software. Some 3100 papers were identified and grouped by period, topic and author origin. The results show that the number of papers published has constantly risen since 1800 , more so over the last decades. For example, the number of papers more than doubled between 2000 and 2009 compared to the previous decade (1990-1999). If this trend continues, the number of publications could double again between 2010 and 2019. This observation is valid for all countries, except for Scandinavian and Baltic countries where the number of related articles has decreased in recent years. The most commonly studied topics are human health and sociology, followed by air quality and pollutants. These results show, among other things, that UF research is thriving and that many scientists appear particularly preoccupied by the impacts of global warming.
\end{abstract}

Key words: urban forests, urban forest management, urban forestry, urban parks, health and forests, urban ecology, urban trees, arboriculture, community forestry, urban woodlands, green spaces, urban forest planning, urban green spaces, research review.

\section{RÉSUMÉ}

La recherche en foresterie urbaine (FU) évolue rapidement. Afin de mieux comprendre cet intérêt accru parmi la communauté scientifique, un recensement exhaustif a été réalisé à partir des publications à caractère scientifique parues de 1800 à 2015. Pour ce faire, 21 mots clés ont été utilisés en interrogeant six bases de données. Les données obtenues ont été recueillies et analysées avec le logiciel de gestion de références Endnote $x 7$. Les quelque 3100 références recensées ont été regroupées par période, par thème et par provenance des auteurs. Les résultats obtenus montrent que le nombre de publications n'a cessé de progresser depuis 1800, et ce plus particulièrement ces dernières décennies. Par exemple, elles ont plus que doublé de 2000-2009 par rapport à 1990-1999. Si la tendance se maintient, elle pourrait encore doubler de 2010-2019. Ce constat est valable pour tous les pays, sauf les pays scandinaves et les pays baltes où le nombre de publications est en baisse ces dernières années. Les thèmes de recherche les plus souvent abordés sont la santé humaine et la sociologie, suivis par la qualité de l'air et les polluants. Ces résultats indiquent, entre autres, que la FU est un champ de recherche florissant et que plusieurs scientifiques semblent préoccupés par les impacts du réchauffement climatique.

Mots clés : Foresterie urbaine, Aménagement des forêts urbaines, Forêts urbaines, Parcs urbaines, Forêt et santé, Écologie urbaine, Arbres urbaines, Arboriculture, Espaces verts

\footnotetext{
${ }^{1}$ Université Laval, Abitibi-Price building, 2405 de la Terrasse, Québec, Quebec G1V 0A6 Canada

"Corresponding author: jacques.larouche@canada.ca

${ }^{2}$ Natural Resources Canada, Canadian Forest Service, Laurentian Forestry Centre; 1055 du PEPS, Stn. Sainte-Foy, Québec, QC, G1V 4C7, Canada

${ }^{3}$ Tree Canada, 43 Eccles Street, Suite B, Ottawa, Ontario K1R 6S3 Canada
} 


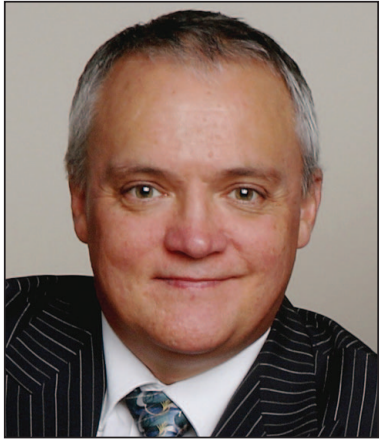

Jacques Larouche

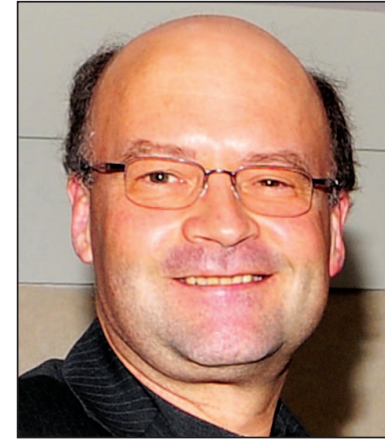

Danny Rioux

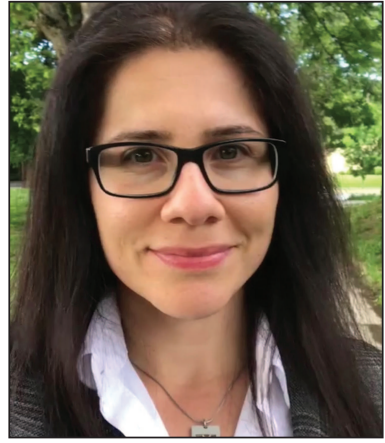

Adrina C. Bardekjian

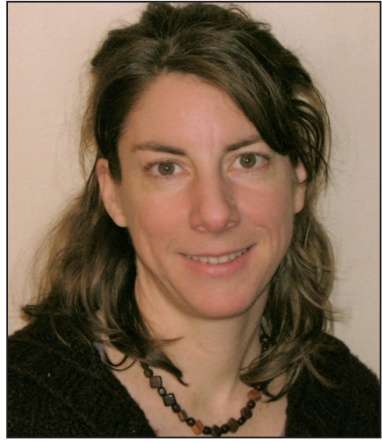

Nancy Gélinas

\section{Introduction}

The world's population is increasingly concentrated in large cities. Regarding populations, Statistics Canada (2017) defines an urban area as "having a population of at least 1000 and a density of 400 or more people per square kilometre." There is no standard definition of an urban area, each country having developed its specific one according to various criteria (World Bank 2015). In 2014 , over $50 \%$ of the world's population lived in urban areas (World Bank 2016a). As this trend continues, this is expected to reach $66 \%$ by 2050 worldwide (FAO 2016). As reported in the last Canadian Urban Forest Strategy (Tree Canada 2019), the 2016 census estimated that $81.1 \%$ of Canadians are urbanites.

Rising urban populations inevitably lead to urban sprawl, which entails various issues such as increased pollution related to road transportation and a greater number of heat islands where the temperature can be $6-8^{\circ} \mathrm{C}$ warmer than in neighbouring green areas (Frumkin 2002). As recognized in the scientific literature for many years, the development and maintenance of urban forests are crucial to countering this issue. For example, healthy urban forests are conducive to sustainable city management (FAO 2016) and contribute to the physical (Donovan et al. 2013; Rao et al. 2014) and mental (Berman et al. 2012) well-being of city populations.

There is a wide consensus regarding the many benefits of urban forests, but the definition of the latter varies greatly (see e.g., Konijnendijk 2003), and generally for our part we like to simply adopt the short one suggested by Bussières et al. (2009): "all trees found within a city's urban boundaries". Such benefits include, for instance, sequestration of gaseous and particulate air pollutants, energy conservation, and storm-water and noise attenuation (Tree Canada 2019). Furthermore, trees in urban areas often face complex and harsh environments, which can, for instance, restrict their access to the various nutrients in the soil (Mullaney et al. 2015). Factors such as contaminated and compacted soils, the presence of de-icing salts, and physical damages caused by snow removal and car activities also undermine their healthy development (Tree Canada 2019). Trees in urban areas are also sensitive to global warming (Ordóñez and Duinker 2014). There must be enough human and financial resources in place to maintain healthy urban tree populations and to take the necessary measures to increase forest cover in municipalities (Johnston and Rushton 1999). It should be noted that, in order to justify such investments, an increasing number of studies estimate the economic value of the benefits generated by trees in urban areas. For example, Alexander and McDonald (2014) estimated that the trees in Toronto are worth CAD $\$ 7$ billion, or $\$ 700$ per tree, whereas Revéret (2017) showed that the positive effects of one hectare of urban forest equates to approximately USD \$32000 per year.

These aspects, which are all critical to creating a healthy urban environment, also constitute potential research topics. According to European analyses, many studies have been carried out in these UF-related fields over the past few decades (Konijnendijk et al. 2000; Ordóñez and Duinker 2014), a number which seems to be still on the rise. This inventory aims to estimate the evolution of research on UF worldwide between 1800 and 2015 with respect to the topics that were studied at various periods. Six bibliographic databases were queried for the purposes of this analysis.

\section{Methods}

Queried databases

The inventory was carried out between May 4 and June 30, 2015. Six different databases were used: Scopus, Cab Abstracts, Geobase, Urban Studies Abstracts, CAIRN, FRANCIS and the Ariane catalogue from the Université Laval's library. Databases were selected following a consultation with a librarian from the Université Laval during a master's degree project (Larouche 2016). These databases are described in Table 1.

\section{Keywords}

The following 21 keywords were used for the purposes of the inventory: "Urban forests," "Urban forests management," "Urban forestry," "Foresterie urbaine," "Aménagement des forêts urbaines," "Forêts urbaines," "Parcs urbains," "Urban parks," "Forêt et santé," "Health and forests," "Urban ecology," "Écologie urbaine," "Urban trees," "Arbres urbains," "Arboriculture," "Community forestry," "Urban woodlands," "Green spaces," "Espaces verts," "Urban forests plan- 
Table 1. Description of the queried databases

\begin{tabular}{lll}
\hline Database & Characteristics & Description \\
\hline Scopus & $\begin{array}{l}\text { Social and applied } \\
\text { sciences, pure } \\
\text { sciences, French }\end{array}$ & $\begin{array}{l}\text { The largest scientific publication database in the world, abstracts are commonly available. } \\
\text { https://www.elsevier.com/solutions/scopus/content }\end{array}$ \\
CAB Abstracts & $\begin{array}{l}\text { Applied sciences, } \\
1910-2015\end{array}$ & $\begin{array}{l}\text { Indexes over 10,000 scientific journals, as well as books, reports, conference proceedings and } \\
\text { minutes. The topics covered include veterinary sciences, agriculture and affiliated fields (e.g., } \\
\text { nutrition and human health), forestry, botany, biotechnology, natural resource management } \\
\text { and conservation (source: Ariane catalogue, Université Laval). } \\
\text { http://sites.cabi.org/Uploads/CABI/publishing/promotional- } \\
\text { materials/insert/Cab\%20Abstracts\%204Pp\%20Flyer\%20French\%20Hr.pdf }\end{array}$ \\
\hline
\end{tabular}

Geobase Includes thousands of peer-reviewed journals, books and conference proceedings on topics
related to the earth sciences, including geology, human and physical geography, environmental
sciences, oceanography, geotechnics, alternative energy sources, pollution, waste management
and nature conservation. https://www.elsevier.com/solutions/engineering-
village/content/geobase

Urban Studies Abstracts

Includes the research fields associated to urban studies, including economics, community development, urban history and other key topics in the field. Data is drawn from several journals such as the Journal of Urban Affairs, Urban Studies, and the Canadian Journal of Urban Research (Ariane catalogue, Université Laval).
CAIRN
Includes analytical summaries and complete texts from European journals in humanities and social sciences (Ariane catalogue, Université Laval).
FRANCIS
Contains over one million records, covering humanities and social sciences from sources worldwide. The topics covered include archaeology, geography, linguistics, philosophy, religion and sociology, drawn from journal articles, conference minutes, works, reports and doctoral theses (source: Ariane catalogue, Université Laval).

Ariane

The search engine of Université Laval's library, indexing all documents (books, journals, theses, etc.) included in its collections.

ning" and "Urban green spaces." One of these keywords had to be found at least once in a publication's abstract or title to be selected for the purposes of the inventory.

\section{Data analysis}

The articles identified during this study were grouped under various topics, based on a set of criteria. To carry out the analysis, the articles were first entered in the Endnote $x 7$ reference management software. The search using the 21 keywords in the six databases yielded over 20000 results. The articles were then sorted to eliminate duplicate entries and irrelevant references. The only publications retained were scientific publications and conference proceedings. Books and theses were excluded since they are usually the product of a collaboration between several authors and have generally involved and/or resulted in the publication of scientific articles. Groups were created, based on research topic, publication period (1800-1969, 1970-1979, 1980-1989, 1990-1999, 2000-2009, and 2010-2015) as well as geographic origin of the authors and articles. Given the small number of articles published between 1800 and 1969 as identified in the databases, and in order to facilitate data analyses, the results in question were included in a group covering a longer period.
Overall, 20 topics were selected in order to limit the number of research groups as much as possible (Table 2). For example, articles on tree health, tree stress and injuries, arboriculture and dangerous trees were grouped under the tree health and arboriculture topic. Regardless of the fact that many of our selected topics (e.g., Ecology, Biodiversity and Management) were also used in other studies (Konijnendijk et al. 2007; Wolf and Kruger 2009), the grouping process remains naturally subjective and alternative classification methods have been used at times.

EndNote shows the location of the publication and the authors' origins. However, after verification, we discovered that the authors' origin stated in EndNote was more often than not the location of the journal's publication. After meeting with a librarian from the Université Laval, we determined that the most appropriate tool to identify the origin of the articles' authors was the Web of Science database. To efficiently use this database to retrace the origin of the articles, we created a new database with the data collected in EndNote $x 7$ and we removed the following single title occurrences: "urban resident", "urban green space", "urban tree", "urban forestry", "urban woodlands", "urban tree inventories" and "urban forestry education". These sin- 


\begin{tabular}{|c|c|}
\hline Category & Description \\
\hline Management & Urban forest management and development \\
\hline Trees and climate in urban areas & The role of trees and urban forests in city climates, including their impact on heat islands \\
\hline Biodiversity, ecology and urban ecosystems & Ecology, ecosystems and biodiversity in urban forests \\
\hline Biomass and physiology & $\begin{array}{l}\text { Biomass of urban forests and tree physiology (exchanges between leaves and air, } \\
\text { aero-dynamism and transpiration) }\end{array}$ \\
\hline Water and wetlands & Wetlands, runoff management and water supply for trees \\
\hline Education and conferences & Conference proceedings and worker training sessions \\
\hline Fauna & Urban forest fauna \\
\hline Geomatics and remote sensing & Uses of geomatics and remote sensing \\
\hline History and definition & History and definition of the urban forest \\
\hline Insects and diseases (indigenous and exotic) & Indigenous and exotic pests \\
\hline Inventory and composition & $\begin{array}{l}\text { Urban tree inventory obtained by a method other than remote sensing and the composi- } \\
\text { tion of urban forests }\end{array}$ \\
\hline Modelling & Model development in relation to urban forests \\
\hline Policy and legislation & Regulations, legislation and policies related to green spaces and trees in urban areas \\
\hline Programs & $\begin{array}{l}\text { Community and public plantation programs as well as urban forest development } \\
\text { programs }\end{array}$ \\
\hline Air quality and pollutants & $\begin{array}{l}\text { Air quality, role of trees in pollutant filtration and allergies induced by various tree } \\
\text { components }\end{array}$ \\
\hline Literature reviews, studies and research needs & $\begin{array}{l}\text { Literature reviews on urban forest publications, studies or surveys, and identification of } \\
\text { research needs regarding urban forests }\end{array}$ \\
\hline Tree health and arboriculture & Tree health, injuries, stress, arboriculture and dangerous trees \\
\hline Human health and sociology & Trees and human health, and sociological aspects of urban forests \\
\hline Soils, tree plantation and selection & Plantation, soils and species selection \\
\hline Tree value & Economic value of forests and value of forest-derived products \\
\hline
\end{tabular}

gle title occurrences were found in many other long titles. For example, if we found the following title: "Urban trees: a survey of street trees in England" and we kept the single tittle occurrence "urban tree", this title would appear twice in the search results of the Web of Science (one time with the long title and a second time with just "urban tree" highlighted). By removing these seven single occurrences before doing our research in the Web of Science, only seven documents were lost as their title was solely composed of these single occurrence terms, instead of having a lot of multi-occurrences of the same title.

We also removed all French titles (8\%), since they were not available in the Web of Science. In order to meet the requirements of this database's search tool and to make the identification of article titles possible, we placed each title in quotes and inserted the boolean operator "OR" after each one. Once the data had been organized, we searched for the titles in the database using the advanced search tool. Afterwards, we opened every identified article to find the first author's origin.

\section{Results and discussion \\ Distribution of urban forestry (UF) publications by period between 1800 and 2015}

Using six different databases and the Ariane catalogue, we were able to cover the period between 1800 and
June 2015. We collected 3,112 documents using our list of selected keywords.

The results indicate a constant increase in the number of UF publications since 1800 . This increase is more notable over the last decades where, for instance, the number of publications have more than doubled between 2000 and 2009 compared to 1990 to 1999 (Fig. 1). It is expected to double again between 2010 and 2019 if this trend continues. Nonetheless, this increase is inferior to that reported in a similar study conducted by Ostoić and van den Bosch (2015) which covered the period from 1988 to 2014. These researchers identified 519 articles published in this period by searching for the keywords "urban forest" in the Scopus database, querying only four specialized journals: Arboriculture and Urban Forestry (AUF), under the name Journal of Arboriculture (JA) until 2006, Urban Forestry \& Urban Greening (UF\&UG), Landscape and Urban Planning (LUP) and Forest Policy and Economics (FPE). They noted a constant increase in the number of publications over the years, a number that tripled between 1990-1999 and 2000-2009. For the last five years covered by the study, i.e., 2010 to 2014, 210 articles were identified. This number represents $40 \%$ of the total. Despite being created only in 2002, UF\&UG published $31 \%$ of the 519 articles. AUF/JA published $44.5 \%$ of the papers, while $L U P$ and FPE issued $23 \%$ and $1.9 \%$, 


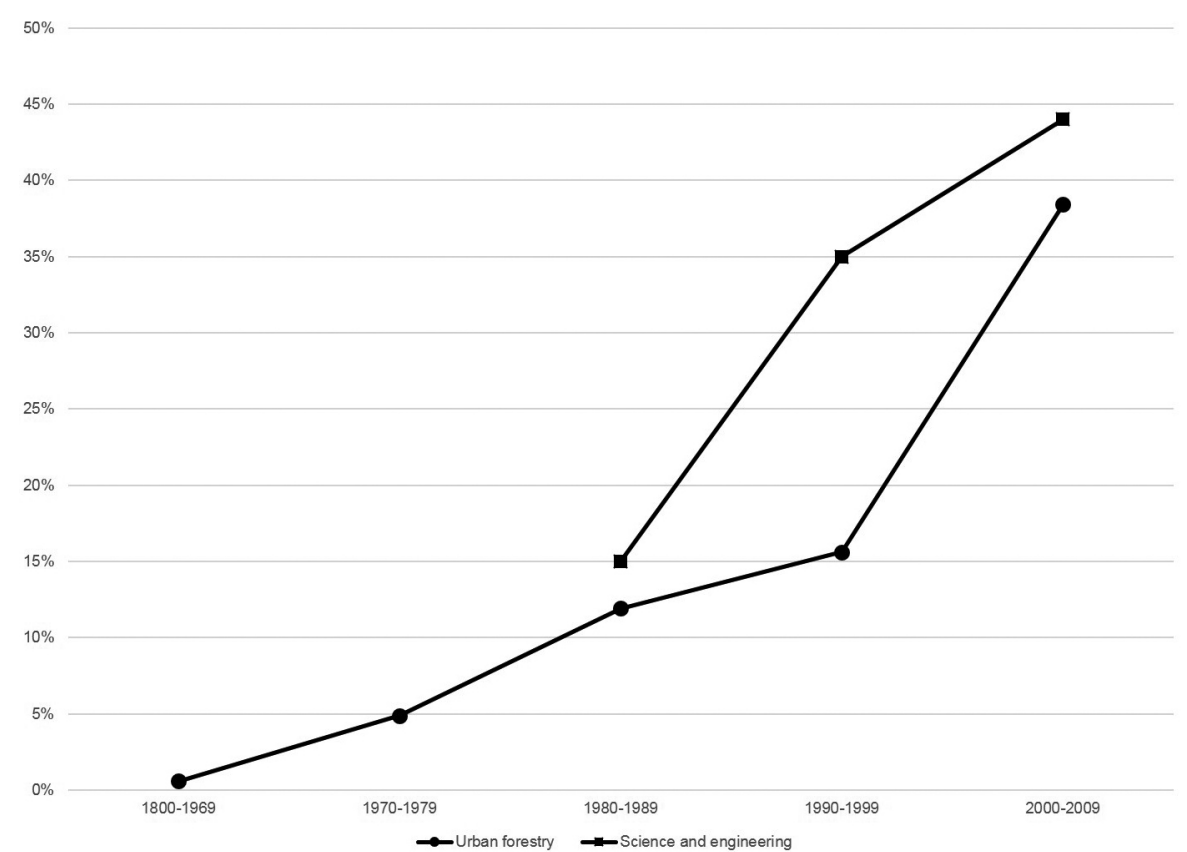

Fig. 1. Global publications in science and engineering ${ }^{4}$ and in the field of urban forestry according to the percentage of publications

${ }^{4}$ Number of science and engineering articles published on physics, biology, chemistry, mathematics, clinical medicine, biomedical research, engineering and technology, and earth and space sciences.

respectively. Another study covering the 159 articles published by UF\&UG between 2002 and 2009 also showed that the journal published an increasing number of articles over the years (Bentsen et al. 2010), this being reflected, for instance, by the fact that the journal went from three to four issues per volume by 2004. The comparison of our study with that of Ostoić and van den Bosch (2015) is not an easy one, partly because we used more keywords and databases. It is interesting to note the increased interest shown by urban forest stakeholders over the past few decades when compared to previous decades.

During a presentation at the $14^{\text {th }}$ World Forestry Congress held in September 2015 in Durban, South Africa, Fabio Salbitano from the University of Florence used a query run in Scopus to show the significant rise in the number of articles published between 2000 and 2010 regarding a specific field of UF, i.e., green infrastructure, as compared with the previous decade (Borelli et al. 2015). Although there is no doubt among key stakeholders concerning the benefits of urban trees, this study shows that concrete actions had recently been taken to ensure the sustainability of the resource and thereby meet citizens' expectations.

A comparison with the global field of "science and engineering" articles published between 1980 and 2009 (World Bank 2016b) indicates that their number increased as well (data available only for this period) (Fig. 1). The increased rate of scientific publications was greater than that of UF publications between 1980-1989 and 1990-1999, but this trend reversed in favour of UF publications when comparing 1999-2009 and 2000-2009.

Distribution of scientific articles in urban forestry by research topic

The Human health and sociology topic (446 publications, $14.3 \%$ of the total) includes the most articles, followed by Air quality and pollutants (281 publications, 9.0\%) and Tree health and arboriculture (268 publications, 8.6\%) (Fig. 2).

These results are comparable to those of similar studies. Ostoić and van den Bosch (2015) reported that the Management topic, which includes all aspects of tree health (e.g., selection, growth, inventory, dangerousness), and therefore overlaps with the Tree health and arboriculture topic in our study, includes $50 \%$ of the publications, while Human health and sociology ranked in second place with $19 \%$ of publications. However, the authors were surprised to note that, over the period covered, very few studies focused on adaptations to climate change and its impact on human health. In another study on UF research projects covering 2005 to 2009 in Denmark, Finland, Norway and Sweden, Molin et al. (2010) showed that, of the 67 studies surveyed and divided into 15 topics, only four themes were cited by specialists in over $20 \%$ of these studies. The Nature and health and Social values topics, which are very similar to Human health and sociology (ranked first in our inventory), tied for third place with $20 \%$ of responses when these topics were grouped by research topic frequency (Molin et al. 2010). Ranking first with a landslide $60 \%$ was the Urban planning topic, while Ecology and biodiversity came in second with $30 \%$. Of the 67 studies, 51 were essentially conducted in universities, 15 in research institutes and one by a governmental department.

The same trend was observed in a study on UF research which was conducted in Europe covering the 1990 to 2000 period and 20 countries (Konijnendijk et al. 2000). The studies were grouped into three topics: Establishment of objectives and functions of urban forests and trees with $40 \%$ of the total, Establishment and selection of trees for urban uses with $32 \%$, and Management of urban forests and urban trees that included $28 \%$. Of the 404 studies surveyed, only three subtopics grouped more than 50: Planning (60, or $14.9 \%$ of the 


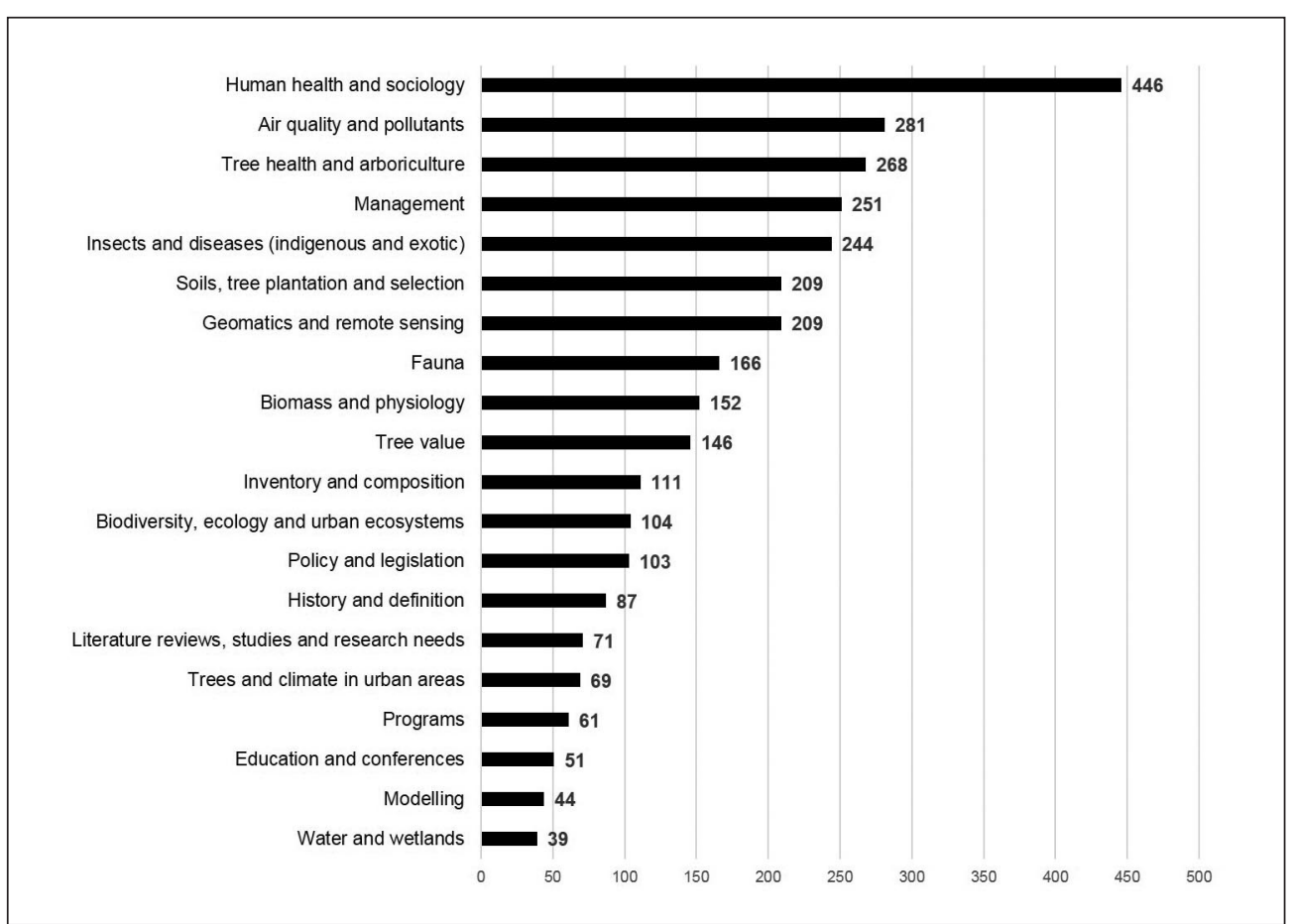

Fig. 2. Distribution of urban forestry articles by topic ( $N=3112$ )

total) and Recreation studies (54 or 13.3\%), being included in the first topic, and Selection and testing of plant material $(60,14.9 \%)$ that was part of the second topic.

Another study, conducted in 2005 by Konijnendijk et al. (2007), focused on UF research carried out in Scandinavian and Baltic countries. This study showed that of the 20 topics selected using 306 keywords, Planning ( 11\%), Ecology and biodiversity $(\sim 10 \%)$ and Management ( $~ 8 \%)$ were standouts. Of the 76 projects described, only six occurred in the Baltic countries (five in Estonia, one in Latvia and none in Lithuania).

The study by Bentsen et al. (2010), which focused on the 159 papers published in Urban Forestry and Urban Greening between 2002 and 2009, is quite instructive regarding the topics selected and quantified over the course of various inventories. The topics chosen by these authors were drawn directly from the study by James et al. (2009) which was published in that same journal in 2009. The topics used in the latter were selected after consulting with 40 UF experts. However, James et al. (2009) clearly mentioned that these topics should be considered as emerging or trendy, although it is surprising to find that the "old" Management theme is one of them. Bentsen et al. (2010) did not mention this aspect in their study. This suggests that certain classic, albeit still current, topics could have been put aside, thereby creating a slight bias in the analysis carried out by Bentsen et al. (2010). These authors also created a new category, Type of science, which included Social sciences (38.4\% of articles), Natural sciences (37.7\%), Multiple disciplines (23.8\%) and Humanities (0\%). As the journal usually does not cover human aspects, the absence of studies in this last field was to be expected. Most specific studies on human health, such as the one carried out in Canada by Crouse et al. (2017) which demonstrated, for instance, significant decreased risks of mortality when citizens' residences were located in areas where greenness was prominent, require considerable investments and are published in journals that are most likely to be read by health-care providers than forestry professionals. Such journals include Lancet Planetary Health, which was chosen by these authors to publish their results. It should be noted that we could not have detected this paper with the use of our keywords, as Crouse et al. (2017) used the keyword "urban greenness" in their title and abstract. Finally, although Konijnendijk was a co-author in the Bentsen et al. (2010) study, the authors candidly admit that it is difficult to compare their topics to those of more detailed surveys conducted by Konijnendijk et al. in 2000 and 2007.

We found certain differences between these studies and our own when it comes to the research topics identified (Tables 2 and 3). However, the beneficial aspects of urban forests for human health, sociology, biodiversity and management are widely present in all these studies, confirming the importance of these research topics. The National Urban and Community Forestry Advisory Council (2006) even includes the aspect of health and well-being in its definition of UF: "Urban forestry is the art, science, and technology of managing trees, forests, and natural systems in and around cities, suburbs and towns for the health and well-being of all people"

Moreover, in a study conducted by Bell et al. (2007) on mapping research priorities regarding green spaces and public spaces in England, these authors identified about 1300 research items in all published in this field over a recent period of 10 years, i.e., from 1995 to 2004. The results clearly indicate that there was a significant amount of research conducted on sociology, although some of the subtopics associated to the works by their authors were only addressed in a piecemeal fashion. Much of the work was related to economics, for example, the impact of the presence of trees and other plants on property prices. The authors were surprised to note that the least studied field concerned Human health and the well-being of citizens, but this only with regard 
Table 3. Inventory study groups used in the literature

\begin{tabular}{|c|c|c|c|c|}
\hline Study & Term & $\begin{array}{l}\text { Number of } \\
\text { studies } \\
\text { considered }\end{array}$ & Main topics & $\begin{array}{l}\text { Number of } \\
\text { countries } \\
\text { covered }\end{array}$ \\
\hline Bell et al. (2007) & 1995-2004 & $\approx 1000$ & $\begin{array}{l}\text { 1. Planning } \\
\text { 2. Biodiversity } \\
\text { 3. Economic values } \\
\text { 4. Social } \\
\text { 5. Management }\end{array}$ & 1 \\
\hline Bentsen et al. (2010) & $2002-2009$ & 159 & $\begin{array}{l}\text { 1. Management of urban green space } \\
\text { 2. Physicality of urban green space } \\
\text { 3. Experience of urban green space } \\
\text { 4. Governance of urban green space } \\
\text { 5. Valuation of urban green space }\end{array}$ & 33 \\
\hline Konijnendijk et al. (2000) & $1990-2000$ & 404 & $\begin{array}{l}\text { 1. Urban forestry/urban green structure planning } \\
\text { 2. Selection and testing of plant material for urban areas } \\
\text { 3. Recreation studies } \\
\text { 4. Establishment of street trees and urban woodland } \\
\text { 5. Typology and monitoring of ecological values }\end{array}$ & 20 \\
\hline Konijnendijk et al. (2007) & 2005 & 76 & $\begin{array}{l}\text { 1. Urban forest planning } \\
\text { 2. Urban forest management } \\
\text { 3. Ecology and biodiversity } \\
\text { 4. Social and cultural value } \\
\text { 5. Recreation and use }\end{array}$ & 6 \\
\hline Molin et al. (2010) & 2008-2009 & 67 & $\begin{array}{l}\text { 1. Urban forest planning } \\
\text { 2. Ecology and biodiversity } \\
\text { 3. Social values } \\
\text { 4. Nature and health } \\
\text { 5. Recreation and use }\end{array}$ & 4 \\
\hline Ostoić et al. (2015) & 1988-2014 & 519 & $\begin{array}{l}\text { 1. Management } \\
\text { 2. Civic involvement } \\
\text { 3. Ecosystem services } \\
\text { 4. Biodiversity } \\
\text { 5. Urban planning }\end{array}$ & 39 \\
\hline
\end{tabular}

to correctly targeted social groups and the types of green spaces analyzed. They also mentioned that this topic was by far the most common among ongoing and planned research. We also focused on the main research topics per period. For the period spanning from 1800 to 1969, Human Health and Sociology was the most studied at $46 \%$ (Fig. 3), despite the small amount of data recorded during this period compared with other topics. For the 1970-1979 and 1980-1989 decades, Urban Forest Management was the preferred topic with 15\%. In 1990-1999, Insects and diseases (indigenous and exotic) prevailed with 14\% while Air quality and pollutants as well as Human health and sociology were the most popular subjects in 2000-2009, each covering $10 \%$ of the research. The latter was still in the lead in 2010-2015, having around $20 \%$ of the total articles identified. It is worth noting that there have been changes in topics over the decades, culminating in recent years with studies primarily focusing on human health and sociology and that most of them essentially reveal that trees provide significant positive benefits for citizens.
In the same sense, in a society that is increasingly concerned with climate change, the effects of pollution on the environment and thereby on human health, the research focusing directly on UF, or indirectly on related fields (Donovan et al. 2013; Makar et al. 2017), highlights the importance of urban forests on the health and well-being of city populations. We hope that all these studies will influence future research projects to better respond to the numerous challenges facing the maintenance of urban forests and to ensure the wellbeing of citizens.

We also noted that the Insects and diseases (indigenous and exotic) topic was under-represented in our study. We believe that the keywords identified did not adequately represent publications on pests. To verify this hypothesis, we resumed the inventory process using the Scopus database and a single key word, i.e., "emerald ash borer" (Agrilus planipennis Fairmaire), an insect which is at the heart of current events causing considerable devastation in forests of North America. We then obtained 441 documents, while only eight concerning this insect had been identified during our 


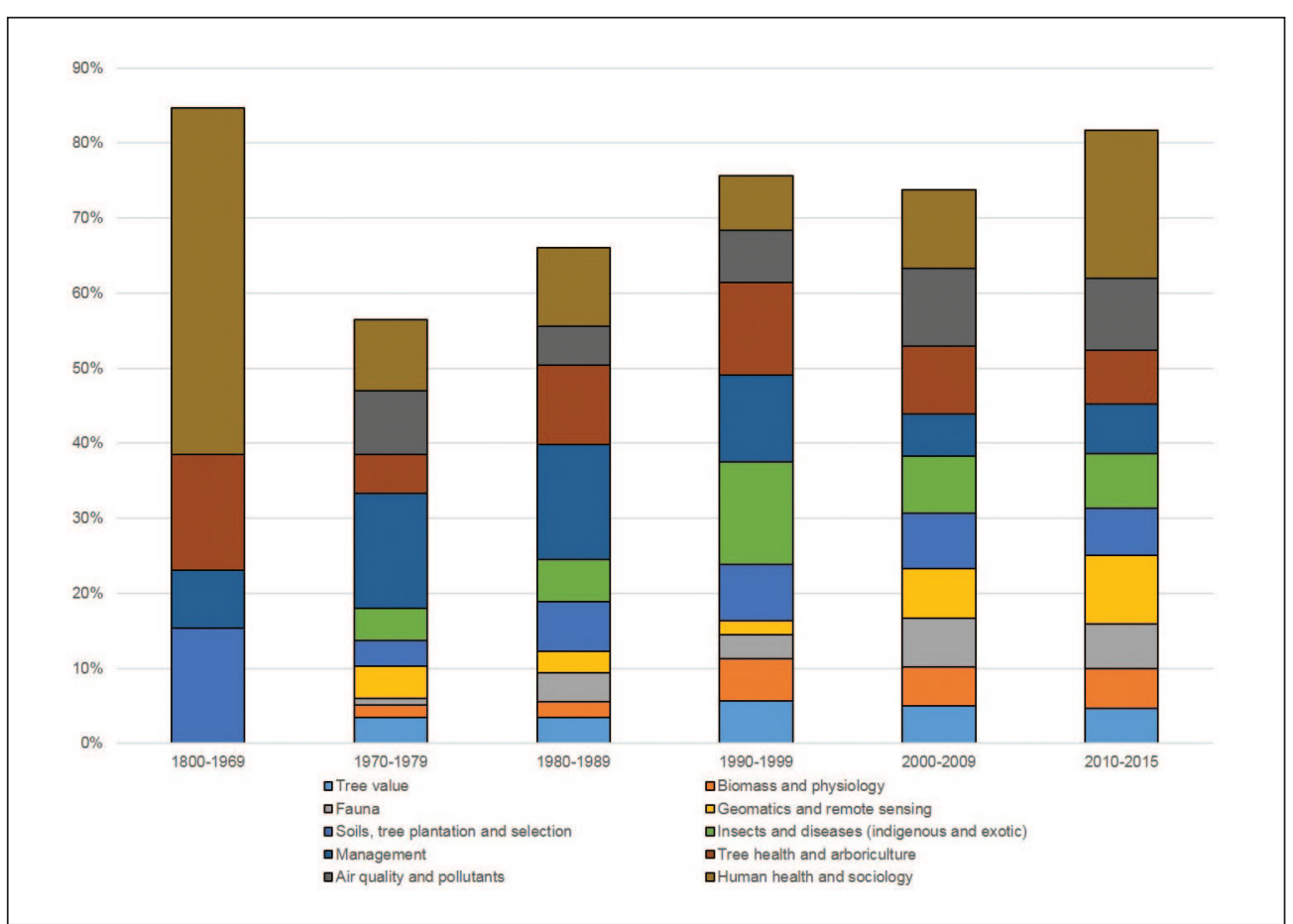

Fig. 3. Distribution of urban forestry publications by topic and period (top 10) ( $N=3112)$

these countries (in 2018, around 327 million cf. 37 million, respectively). North America therefore accounted for $61 \%$ of the 519 papers identified by these authors, as no studies seemed to originate from Mexico in that inventory, whereas five were identified during our study (Table 4). Although our regional groups and the number of articles analyzed (519 vs. 1265 ) differ, as well as the queried databases (1 vs. 6) and the keywords used (1 vs. 21 ), our results are similar in many respects. Moreover, if we were to apply the same groups as those presented in Table 4 to the results of the Ostoić and van den Bosch (2015) study, we would obtain the follow-

original query using 21 keywords. Thus, to investigate the question of insects and diseases, a specific inventory using the Latin names and even the common names of pests is recommended.

\section{Distribution of urban forestry publications by origin}

The geographic origin of the authors was only possible using the Web of Science database. Of the 3112 documents found, only the 2838 documents published in English were considered for this analysis, since Web of Science does not index papers published in French for instance. Using the database with these documents, it was possible to identify the origin of the authors for only $43 \%$ (1227) of the studies. The authors hail from 64 different countries which we grouped into 11 regions for the purposes of our analysis (Table 4). This table shows, among other things, that the number of articles published on UF is particularly high in North America (466), followed by Central Europe (214) and Asia (214). Another recent study (Ostoić and van den Bosch 2015) also showed that most of the articles on urban forestry came from North America, followed by Europe. The contribution of other countries was negligible. The authors noted, unsurprisingly, that the first place for North America is likely linked to the fact that the very concept of urban forestry was first expressed in Canada (Jorgensen 1974). Until the early 2000s, the main journal in the field was $J A$, whose name was changed to Arboriculture and Urban Forestry in 2006. This journal is published by the Illinois-based International Society of Arboriculture. The United States ranked first with 287 publications and 30 were from Canadian authors, data quite proportional to the respective populations of ing in order of importance: North America, Scandinavian countries, Asia, Central Europe, Oceania and the United Kingdom. The same six regions top our list, albeit in a slightly different order, the notable exception being North America which came in first place in both studies.

We also addressed the evolution of the articles over time according to the location of the journal in which the article was published (Fig. 4). The location of publication was identified using EndNote $x 7$, with which we were able to find the origin of 1265 articles. Every region published an increasing number of papers in the period 2010-present compared with 2000-2009, including Africa, Great-Britain and the Middle East, with the exception of Scandinavian and Baltic countries, where a drop was observed. Publications sorted by country and by decade generally follow the upward trend observed over time for all urban forestry publications.

\section{Conclusion}

This inventory, which is the most comprehensive of its kind focusing on urban forestry publications, has demonstrated that research conducted in the field is ever-growing. In fact, the number of research projects is rising considerably in most regions of the world, especially since 2000-2009 when the number of articles more than doubled compared to the previous decade. This trend also reflects the total number of scientific publications rather accurately but is even more pronounced in the field of urban forestry, and this even since 1990. Our analysis also revealed that North America, Central Europe and Asia accounted for the greatest 
Table 4. Number of authors in 11 country groups *

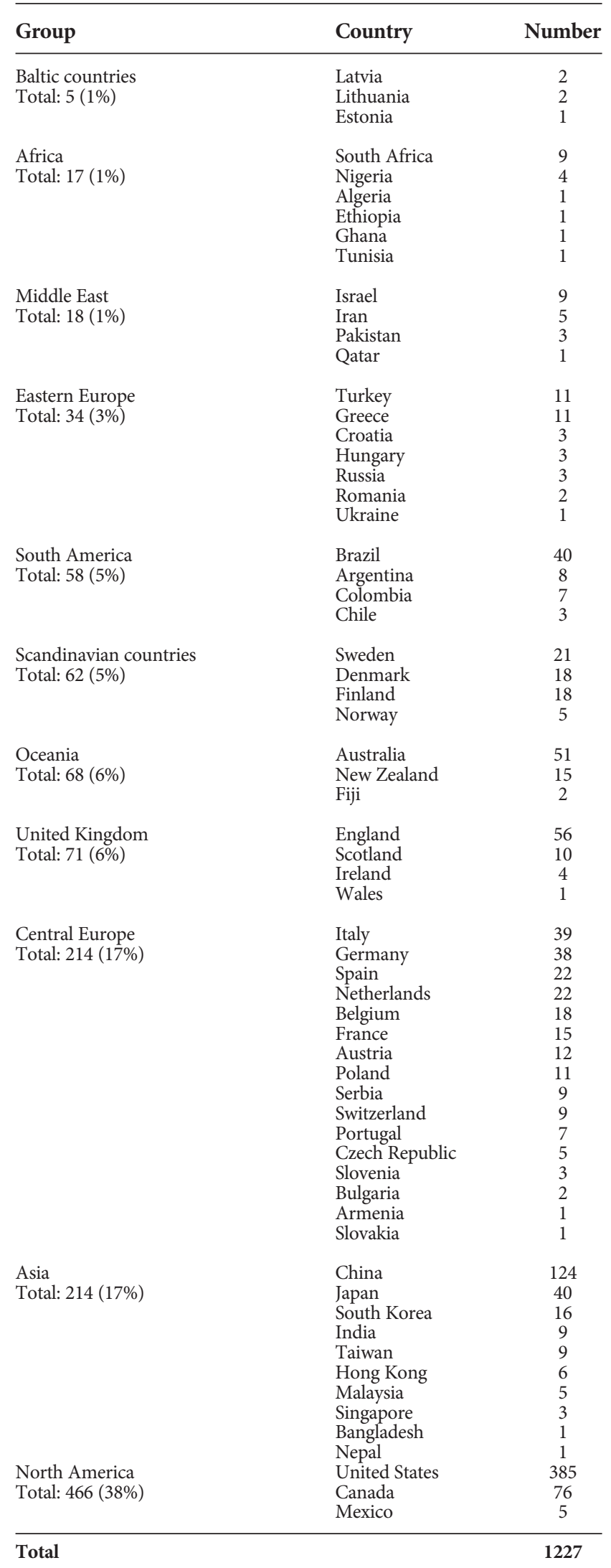

${ }^{*}$ Distribution of the 1227 authors of the selected urban forestry publications between 1970 and 2015 according to the first author's country of origin number of studies in urban forestry. We noted that publications on human health, including pollutionrelated issues, are of increasing interest to specialists in the field. These specialists demonstrate through their studies that managing urban trees more efficiently has a positive and significant effect on the quality of life of city populations. It is expected that the adverse effects of climate change on the urban dweller will only become worse in the coming years, particularly illnesses related to heat islands. Even if gaps have been reported in the number of studies on the topic over the past few years, it is reasonable to assume that they will increase in number in the future and that their impact will lead managers to take the necessary measures to increase the forest cover in cities, especially in strategic areas.

This extensive inventory is the first of two. The next study will focus on identifying the research needs of Canadian cities, based on a widespread consultation of UF authorities throughout Canada conducted in 2015. We will analyze the relationships between these needs and the nature of the articles published to date, namely, in recent years. This will allow us to determine the most relevant research needs and to detect any discrepancies, such as a city need in a particular area while there is already plenty of studies in the literature, apparently unknown to city urban forest specialists consulted during the survey.

\section{Acknowledgements}

We thank Eve Richard, forestry engineer, M.S.I., and librarian at Université Laval for her support and helpful advice when selecting the databases and the analysis methodology. We also thank Guy Bussières, forestry engineer, in charge of practical work and research, Faculty of Forestry, Geography and Geomatics at Université Laval and Louis Bernier, professor, Faculty of Forestry, Geography and Geomatics at Université Laval, for their valuable advice.

\section{References}

Alexander, C. and C. McDonald. 2014. Urban forests: The value of trees in the City of Toronto. Special Report. TD Economics, 4 p.

Bell, S., A. Montarzino and P. Travlou. 2007. Mapping research priorities for green and public urban space in the UK. Urban For. Urban Gree. 6: 103-115

Bentsen, P., A.C. Lindholst and C.C. Konijnendijk. 2010. Reviewing eight years of Urban Forestry \& Urban Greening: Taking stock, looking ahead. Urban For Urban Gree. 9(4): 273-280.

Berman, M.G., E. Kross, K.M. Krpan, M.K. Askren, A. Burson, P.J. Deldin, S. Kaplan, L. Sherdell, I.H. Gotlib and J. Jonides. 2012. Interacting with nature improves cognition and affect for individuals with depression. J. Affect. Disorders 140(3): 300-305.

Borelli, S., Y. Chen, M. Conigliaro and F. Salbitano. 2015. Green infrastructure: A new paradigm for developing cities. XIV World Forestry Congress, Durban, 8 p.

Bussières, G., P. Brochu, M.-J. Coupal, F. Fradette, P. Francoeur, J. Larivière, B. Paquet, É. Rey-Lescure, M.-C. Robert, P.-É. Rocray and C. Sommeillier. 2009. "Foresterie urbaine " dans Ordre des ingénieurs forestiers du Québec, Manuel de foresterie, $2^{\mathrm{e}}$ éd. Ouvrage collectif, Éditions MultiMondes, Québec, pp. 721-769.

Crouse, D.L., L. Pinault, A. Balram, P. Hystad, P.A. Peters, H. Chen, A. van Donkelaar, R.V. Martin, R. Ménard, A. Robichaud and P.J. Villeneuve. 2017. Urban greenness and mortality in 


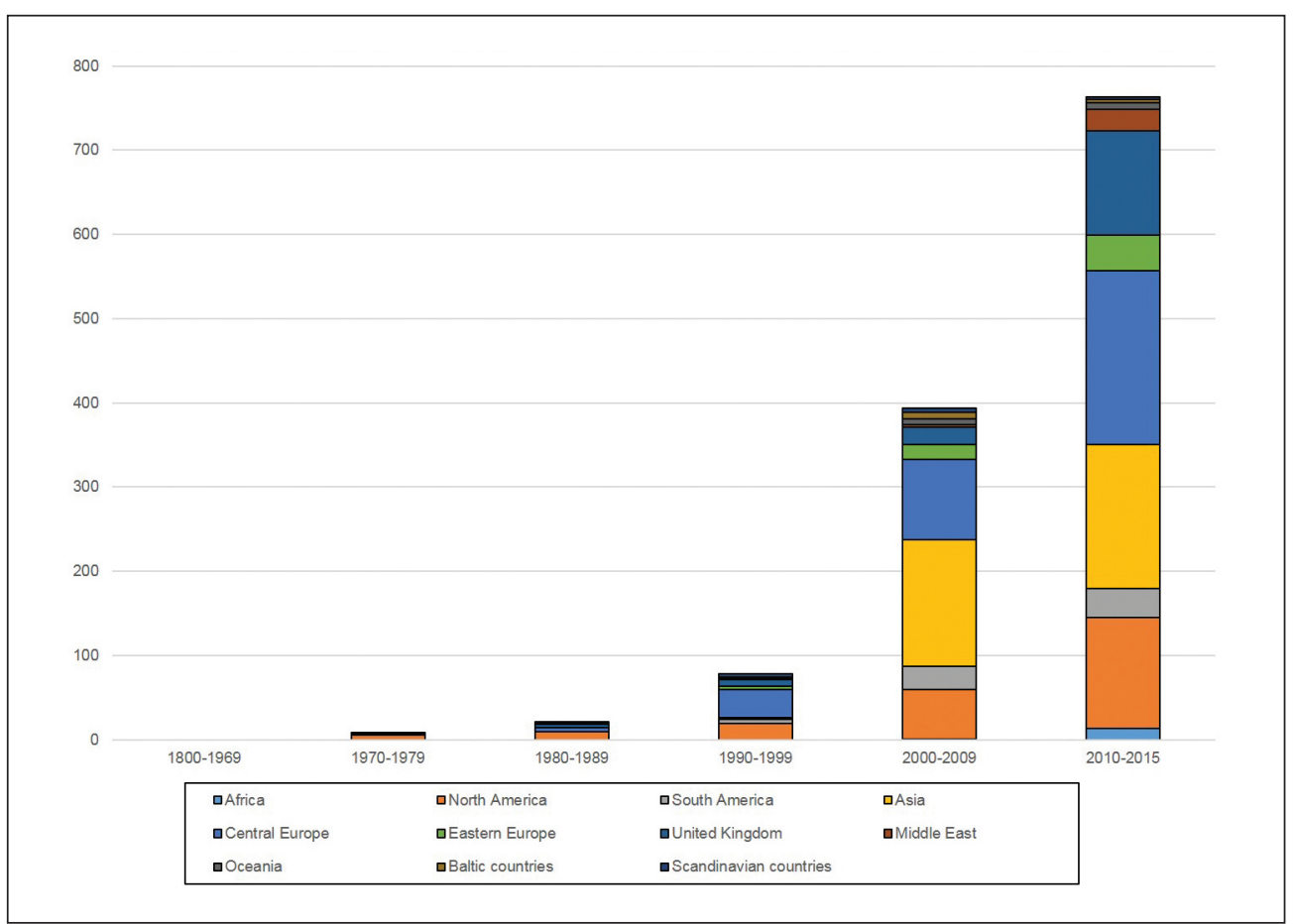

Fig. 4. Distribution of publications according to location and period between 1800 and 2015 ( $N=1265$ )

Makar, P.A., R.M. Staebler, A. Akingunola, J. Zhang, C. McLinden, S.K. Kharol, B. Pabla, P. Cheung and Q. Zheng. 2017. The effects of forest canopy shading and turbulence on boundary layer ozone. Nat. Commun. 8:15243. 14 p.

Molin, J., C.C. Konijnendijk, J. Schipperijn, K. Mäkinen, M. Sipilä, L. Tyrväinen, V. Gundersen, A.B. Nielsen and G. Richnau. 2010. Review of urban forestry research in the Nordic countries. 2009 update. A Nordic-Baltic Centre of Advanced Research on Forestry serving Nordic Urban Societies Report. Denmark. 29 p.

Mullaney, J., T. Lucke and S.J. Trueman. 2015. A review of benefits and challenges in growing street trees in paved urban environments. Landscape Urban Plan. 134: 157166.

National Urban and Community Forestry Advisory

Canada's largest cities: a national cohort study. Lancet Planet Health 1: e289-97.

Donovan, H.G., D.T. Butry, Y.L. Michael, J.P. Prestemon, A.M. Liebhold, D. Gatziolis and M.Y. Mao. 2013. The relationship between trees and human health. Evidence from the spread of the Emerald Ash Borer. Am. J. Prev. Med. 44(2):139-145.

FAO. 2016. (Food and Agriculture Organization of the United Nations). Sustainable Forest Management (SFM) Toolbox. [Online] Available at http://www.fao.org/sustainable-forest-management/toolbox/modules/urban-and-peri-urban-forestry/basicknowledge/en/. [Accessed July 10, 2019].

Frumkin, H. 2002. Urban sprawl and public health. Public Health reports, May-June 17: 201-217

James, P., K. Tzoulas, M.D. Adams, A. Barber, J. Box, J. Breuste, T. Elmqvist, M. Frith, C. Gordon, K.L. Greening et al. 2009. Towards an integrated understanding of green space in the European built environment. Urban For. Urban Gree. 8: 65-75.

Johnston, M. and B. Rushton. 1999. A survey of urban forestry in Britain. University of Ulster. Northern Ireland. 36 p.

Jorgensen, E. 1974. Towards an urban forestry concept. Prepared for the 10th Commonwealth Forestry Conference, Oxford and Aberdeen, Britain, Environment Canada, 14 p.

Konijnendijk, C.C. 2003. A decade of urban forestry in Europe. Forest Policy Econ. 5: 173-186.

Konijnendijk, C.C., T.B. Randrup and K. Nilsson. 2000. Urban forestry research in Europe: An overview. J. Arbor. 26(3): 152-161. Konijnendijk, C.C., A.B. Nielsen, J. Schipperijn, Y. Rosenblad, H Sander, M. Sarv,K. Mäkinen, L. Tyrväinen, J. Donis, V. Gundersen, U. Åkerlund and R. Gustavsson. 2007. Assessment of urban forestry research and research needs in Nordic and Baltic countries. Urban For. Urban Gree. 6: 297-309.

Larouche, J. 2016. Foresterie urbaine: recensement mondial des publications, situation actuelle et besoins de recherche des municipalités canadiennes. Mémoire de maîtrise en sciences forestières. Université Laval, Québec (QC). https://corpus.ulaval.ca/jspui/ handle/20.500.11794/26951 [Accessed July 10, 2019]
Council. 2006. Ten-year action plan (2006-2016). US For. Serv., Washington, DC. 11 p.

Ordóñez, C and P.N. Duinker. 2014. Assessing the vulnerability of urban forests to climate change. Environ. Rev. 22: 311-321.

Ostoić, S.K. and C.C.K. van den Bosch. 2015. Exploring global scientific discourses on urban forestry. Urban For. Urban Gree. 14: $129-138$.

Rao, M., L.A. George, T.N. Rossentiel, V. Shandas and A. Dinno. 2014. Assessing the relationship among urban trees, nitrogen dioxide, and respiratory health. Environ. Pollut. 194: 96-104.

Revéret, J.-P. 2017. Valeur économique des effets sur la santé de la nature en ville. Québec: Institut national de santé publique du Québec. [Online] Available https://www.inspq.qc.ca/sites/default/ files/publications/2267_valeur_economique_effets_sante_nature_ ville_revisee.pdf [Accessed July 10, 2019].

Statistics Canada. 2017. Canada goes urban. [Online] Available at https://www150.statcan.gc.ca/n1/pub/11-630-x/11-630-x2015004eng.htm. [Accessed July 10, 2019].

Tree Canada. 2019. Canadian Urban Forest Strategy 2019-2024. https://reecanada.ca/wp-content/uploads/2018/10/TC-CUFS2019-2024-Eng-1.pdf [Accessed June 26, 2019].

Wolf, K.L. and L.E. Kruger. 2009. Urban forestry research needs: A participatory assessment process. J. Forest. January/February p. 39-44. World Bank. 2015. What does "urban" mean? [Online] Available at https://blogs.worldbank.org/sustainablecities/what-does-urbanmean [Accessed July 9, 2019].

World Bank. 2016a. Urban Population (\% of total). [Online] Available at https://data.worldbank.org/indicator/SP.URB.TOTL.IN.ZS. [Accessed July 10, 2019].

World Bank. 2016b. World Development Indicators. [Online] Available at http://databank.worldbank.org/data/reports.aspx? source $=2 \&$ Topic $=14$. [Accessed July 10, 2019]. 